\title{
Social protectionist bias: The domestic politics of North-South trade agreements
}

The British Journal of Politics and International Relations I-20

(C) The Author(s) 2020 Article reuse guidelines: sagepub.com/journals-permissions DOI: |0.1 I77/|369|48|209|099| journals.sagepub.com/home/bpi

@SAGE

\author{
Evgeny Postnikov' ${ }^{(D)}$ and Ida Bastiaens ${ }^{2}$
}

\begin{abstract}
North-South preferential trade agreements (PTAs) have proliferated rapidly in the past decades. Despite a common focus on trade liberalisation, these preferential trade agreements differ greatly in their inclusion of labour and environmental provisions. A difference in the enforcement of these social standards is also puzzling: some preferential trade agreements envision sanctions for non-compliance while others do not. What explains this variation? We argue that Northern governments have their hands tied by domestic constituents demanding social standards as a key protectionist instrument. However, different electoral rules moderate the success of these demands. Because majoritarian systems provide a more efficient channel for the mobilisation of protectionist interests, they are more prone to social protectionist bias than their proportional representation counterparts. We assess our hypotheses using panel regressions of all NorthSouth preferential trade agreements. Our analysis refines previous findings on tariff and nontariff protectionist bias in majoritarian systems and shows how it is manifested in the design of preferential trade agreements.
\end{abstract}

\section{Keywords}

electoral system, environment, labour, preferential trade agreements, protectionism, social standards

\section{Introduction}

Non-trade issues, such as labour and environmental provisions, have become a recurring feature of North-South (N-S) preferential trade agreements (PTAs) (Lechner, 2016; Milewicz et al., 2016). In these PTAs, developed countries often demand that their Southern trading partners commit to improving labour and environmental regulations to prevent a race to the bottom in exchange for market access. Yet, the design of such social standards varies greatly across N-S PTAs. Some countries, like New Zealand, include primarily environmental provisions, while many others, like the United States, demand the fulfilment of

\footnotetext{
'University of Melbourne, Parkville, VIC, Australia

${ }^{2}$ Fordham University, Bronx, NY, USA

Corresponding author:

Evgeny Postnikov, University of Melbourne, Parkville, VIC 30I0, Australia.

Email: evgeny.postnikov@unimelb.edu.au
} 
both environmental and labour commitments. Furthermore, the degree of enforcement of social standards varies cross-nationally. For example, non-compliance with labour or environmental standards in US PTAs is punished with the cancellation of trade preferences or the imposition of a fine. Other developed states, such as the European Union (EU) members, do not include sanctions and instead, rely on dialogue and civil society cooperation for implementation and enforcement.

What are the sources of this variation in coverage and enforcement of social standards? While issue-linkage in N-S trade relations and the emergence of non-trade issues have been explored in many studies (Hafner-Burton, 2005; Kim, 2015; Lechner, 2016), insufficient attention has been given to variations in PTA design. Scholars acknowledge the propensity of democratic systems to be both pro-free trade (Milner and Kubota, 2005) and exhibit hidden protectionism (Kono, 2006), but they fail to clarify predictions about the locus and strength of these features. Our article is among the first to address this gap by focusing on the previously overlooked phenomenon of social protectionism.

We argue that the design of social standards in N-S PTAs is a function of domestic trade policy-making institutions, in particular, the electoral rules of the Northern state. Labour and environmental standards might be viewed as a form of (social) protection aimed at preventing trade-induced job losses. At the same time, this protection is viewed favourably by constituencies who want free trade to be fair. International Political Economy (IPE) scholars have long argued that electoral systems affect the degree of protectionism: majoritarian (or plurality) systems tend to have higher levels of tariffs and subsidies compared to proportional representation (PR) systems (Evans, 2009; Grossman and Helpman, 2005; Rickard, 2012a). We test whether this logic travels to a different type of protection increasingly prevalent in N-S PTAs, social standards, while highlighting a unique political logic of this novel type of protectionism.

Specifically, we hypothesise that N-S PTAs signed by Northern countries with plurality systems will have relatively stronger social standards. Their agreements will contain both labour and environmental protections and more coercive enforcement mechanisms. PTAs signed by Northern states with PR or mixed systems will be weaker, that is, they will include fewer (or no) social provisions and have limited or softer (or no) enforcement mechanisms. Our logic is that governments face differing demands for the inclusion and enforcement of social standards: concentrated domestic interests incurring major losses from trade view enforceable social standards as a form of protection, whereas larger constituencies favouring free and fair trade perceive them as a public good. Electoral institutions determine whose voices get heard and how governments make a trade-off between the enforcement (i.e. social protection) and inclusion (i.e. fairer trade) of social standards. To test our hypotheses, we employ ordered probit analyses with robust standard errors of data on electoral institutions from the Database of Political Institutions (DPI) and N-S PTAs from Dür et al. (2014). We code the degree of social issue coverage and enforcement in each PTA in our dataset. Our empirical analysis reveals that majoritarian governments tend to use all available tools of protection, including social standards, to shield domestic constituents from the high costs of bilateral trade liberalisation. PR governments are more likely to respond to fair traders with less defined policy preferences over specific design of PTAs. Considering that PTAs have become the main vehicle to eliminate all traditional tariff and non-tariff barriers (NTBs) in today's global economy, our analysis is the first one to identify and demonstrate how a different type of protection might thrive when traditional tools are no longer a viable political option. Our findings are also particularly pertinent considering the robust evidence that the design of social 
standard matters for their effectiveness (Bastiaens and Postnikov, 2017; Kim, 2012; Postnikov and Bastiaens, 2014).

\section{Institutional determinants of PTA design}

IPE scholarship provides robust evidence that electoral systems design influences the degree of protectionist bias. Grossman and Helpman (2005) were the first to show that majoritarian governments will be more protectionist than their PR counterparts. They argue that majoritarian electoral systems typically represent fewer electoral districts and are, therefore, likely to maximise the welfare of those districts as opposed society as a whole. PR systems tend to prioritise the latter. Examining tariff levels, Evans (2009) corroborates this protectionist bias among majoritarian governments. Scholars also point to the increasing use of NTBs by governments who wish to protect domestic industries and still comply with the World Trade Organization (WTO; Kono, 2006). And, just as with tariffs, NTB levels are also lower in PR systems (Mansfield and Busch, 1995). Rickard (2012a) further extends the logic of protectionist bias to subsidies and provides additional support for Grossman and Helpman's (2005) theory. Other mechanisms or institutional features - such as the size of winning coalition, party discipline, or seat-vote elasticity are less robust in explaining the protectionist bias (Bueno de Mesquita et al., 2003; Ehrlich, 2007; Rogowski and Kayser, 2002).

Lechner (2016) examines the inclusion of non-trade issues in PTAs, arguing that their degree of legalisation is driven by characteristics of the Southern trading partner. She points to downwards pressures on domestic wages and disparities between agreement partners on civil and political rights. However, her analysis groups together various nontrade issues serving different functions in PTAs (such as human rights and environmental provisions) and leaves the question of enforceability largely unanswered. Studies highlighting fair trade preferences of the constituents in the Global North as a determinant of social standards in PTAs also do not explain differences in the design or incorporation of labour and environmental clauses (Ehrlich, 2010). Furthermore, the design and templates of N-S PTAs remain quite constant across agreements signed by various countries (Baccini et al., 2014).

Importantly, with the stalemate in the WTO, bilateral trade liberalisation through PTAs has become a main policy option for governments desiring further benefits of free trade. Considering that PTAs lower tariffs and increasingly counter NTBs, governments' options have become more and more limited when it comes to domestic protection. We argue that domestic regulation can be seen as distinct form of protection widely used by governments across the world. Kono (2006) shows how democracies are especially prone to use 'less transparent' NTBs to 'optimally obfuscate' their protectionist zeal. In the same vein, social standards are highly visible to voters afraid of competition from abroad, while also having the veneer of fair trade.

Social standards, for example, can be touted as a low-cost mechanism to level the playing field for workers and firms in the developed world faced with fierce competition from developing countries. Ehrlich $(2010,2018)$ demonstrates how social standards are also a tool to satisfy fair trade-minded constituents. Governments are therefore motivated to include these standards in PTAs to satisfy the demands of various voting groups. While PTAs are often driven by producers interested in gaining access to new markets and protecting their investment abroad (Manger, 2009), they can still be considered battlegrounds for different societal actors lobbying to achieve other trade and non-trade objectives. The 
design of PTAs is where these domestic political battles are fought (Lechner, 2016). ${ }^{1}$ Accordingly, PTAs serve a dual role, both liberalising trade and responding to protectionist constituencies due to their preferential nature, as trade policy scholars have long argued (Bhagwati and Panagariya, 1996).

We start with the assumption that some constituent voices will be better represented in the negotiation process than others (and that this is not necessarily proportional to their size). Exporter interests tend to get the upper hand when governments consider joining a PTA. Global supply chains in N-S trade relations (which tend to proliferate further through PTAs) empower producers who favour open trade (Meckling and Hughes, 2017). Yet, to pass trade agreements, governments must also make concessions to constituencies mobilised against them. Societal interests who view labour and environmental provisions as a form of compensation for or protection from free trade will have strong incentives (and capacity) to mobilise. They will use existing institutional channels to translate their preferences over the design of PTAs into the final agreement text. The diffuse pro-fair trade constituency, on the other hand, may demand the inclusion of social standards in PTAs but will often face a collective action problem and not be decisive in terms of their final shape.

We argue that domestic institutions should moderate the effectiveness of these various constituents' lobbying pressures and the size of concessions granted to them. Dean (2015), for instance, shows how domestic profit-sharing institutions, including labour laws, influence the ability of capital to credibly commit to sharing profits with workers. Yet, depending on the institutional context, governments and capital are likely to commit to other types of profit-sharing arrangements (i.e. social protections in PTAs) for key constituents opposing free trade. PTAs empower exporters, but also encourage rent-seeking (see Betz, 2017). The empirical question is, to what extent do governments use social regulation to protect trade liberalisation losers and how do electoral rules influence the extent of protection provided? Specifically, does the social protectionist bias exist in plurality systems in the current era of trade bilateralism? The next section offers a theory of this kind of bias in N-S PTAs.

\section{The role of electoral systems in determining social standards variation in PTAs}

In line with the open economy politics (OEP) approach, we argue that the inclusion and degree of enforcement of social standards in N-S PTAs is the result of Northern governments responding to societal demands, such as labour and environmentalists (Lake, 2009). We assert that domestic institutions moderate these mobilisation pressures, as well as government responses to them.

Electoral rules influence both interest representation and economic policy outcomes (Rogowski, 1987). Plurality systems, in particular, are conducive to the development of a personal vote within each electoral district and encourage interest group lobbying through a direct electoral connection. Logrolling is also more likely in such systems where marginal districts matter a great deal. Such logrolling has been identified as a key mechanism explaining the passage of protectionist measures through the US Congress (Weingast et al., 1981). In proportional systems, on the other hand, political parties appeal to one national constituency, so interest groups have less weight in the policy-making process. Instead, larger constituencies, including consumers, are better represented, leading to less protectionist pressures. Consequently, as discussed previously, scholarly evidence points 
to the effect of electoral institutions on the level of trade and industrial protectionism: politicians representing smaller-sized constituencies are more likely to support protectionist policy (see also Hankla, 2006; Kono, 2009). We assert that the same logic should apply to other special interests with high stakes in trade policy.

Differing from the pro and anti-tariff constituencies, organised labour and environmentalists are two of the main beneficiaries of social standards in PTAs. Labour standards ensure a more level playing field in wages and working conditions across Northern and Southern trading partners. Furthermore, by requiring governments to maintain and improve their levels of environmental protection, environmental standards prevent developing countries from becoming pollution havens. Thus, environmental standards also attenuate the fears of competition among low-skilled workers often employed in polluting industries. By signing PTAs with environmental standards, Northern governments also signal to their constituents that their commitment to address climate change will not lead to jobs being offshored to dirtier jurisdictions (Lechner, 2018). Therefore, governments include such standards in trade deals as a side payment to societal losers from trade liberalisation to ensure their support for an agreement. Both organised labour and green protectionists would ideally like to see fully enforceable labour and environmental standards in all PTAs, that is, sanctions - or full withdrawal of trade privileges - for non-compliance, akin to agreements' commercial clauses. These preferences are well documented in position papers published during the course of trade negotiations. ${ }^{2}$ At the same time, loosely organised interests, including fair trade consumers and larger environmental constituencies would also like to see PTAs linked with social standards, but their preference intensity over the specific design of those provisions is lower than that of the groups with projected economic losses, such as organised labour.

Concurrently, businesses view social standards as a cheap, minimally trade-distorting concession to get trade liberalisation through the legislature and secure their investment abroad (Manger, 2009). Position papers from major business associations in the developed world show that organised businesses do not favour trade agreements with social clauses. ${ }^{3}$ However, this opposition does not manifest itself at the ratification stage. Furthermore, social standards can generate investment in greener industries abroad, as argued by Lechner (2018), which means business interests might be converging with those of environmentalists.

Building on the aforementioned literature on trade protectionism, we argue that, in majoritarian systems, these organised labour and environment interest groups are likely to prevail. In plurality systems, marginal electoral districts exercise more influence and personal votes matter more (Nielson, 2003). Furthermore, labour or environmentalists' lobbying is more effective because of their direct access to members of parliament (MPs) whose re-election depends on their support. Under such conditions, labour and environmentalists are also motivated to lobby together to increase their chances for success and gain support from a larger pool of MPs. Even if labour is traditionally well-organised and environmental interests are relatively more diffuse, Baptist and bootlegger coalitions between the two constituencies are likely to be formed under the plurality rule which would lead to stronger, more enforceable regulation (Yandle, 1999). ${ }^{4}$ Logrolling among pro-labour and pro-environment MPs further ensures that societal interests from marginal districts are satisfied.

This situation is quite different in PR systems. Governments are comprised of cohesive political parties with strong internal discipline. The electoral success of MPs in PR systems is not predetermined on wining marginal or contested electoral districts. Thus, 
the capture of MPs by special interests is less likely in PR systems. Furthermore, the logic of coalition governments, which are often an outcome of PR rules, necessitates political compromise for parties to stay in office. All political parties, including those campaigning on environmental platforms, must therefore appeal to a broader national constituency. Therefore, diffuse consumer interests favouring cheap imports and fair trade are more likely to be satisfied than preferences of organised interest groups, such as labour and environmentalists.

In fact, constituents in the developed world are increasingly fair-trade minded and view social standards as a genuine fair trade mechanism (Bastiaens and Postnikov, 2019; Ehrlich, 2010, 2018). This loosely organised fair constituency views social standards as a global public good due to their promise to improve human and labour rights and fight environmental degradation across the globe. Hence, PR governments may be inclined to include social standards in PTAs because of an overarching constituent demand for these provisions. Yet, we argue that the intensity of preferences over the specificities of social standards' design will be lower in PR systems. We assert that the largest material gains from PTA social provisions would accrue to more specific interests, including low-skilled workers (and unions representing them) often employed in geographically concentrated industries (Rickard, 2012b). Governments face relatively more pressure from these concentrated industries and unions who view social protection as a private good (i.e. a substitute for tariffs) than from fair trade voters who view social provisions as a public good. Therefore, PR governments often include a social protection clause favoured by the public (e.g. environmental) but also work out an internal consensus within the coalition government that results in the lowest common denominator approach, that is, a soft, no-sanctions approach. Labour and environmentalists are also less likely to join forces in PR systems due to the absence of logrolling incentives. Importantly, while PR governments may be more likely to provide higher levels of public goods domestically (Lizzeri and Persico, 2001), free trade benefits the broader domestic constituency by lowering prices. ${ }^{5}$ We thus expect that PR governments may be willing to include some social provisions in PTAs but would not face sufficient pressure to make them broad in scope or fully enforceable through sanctions.

In short, social standards are a unique instrument serving ideologies and policy preferences of societal groups orientated towards both economic nationalism (globalisation losers) and liberal internationalism (fair traders) which makes them highly attractive to governments across the developed world who now include them in nearly all trade deals (Bastiaens and Postnikov, 2019). At the same time, the relative weight of these groups in the policy-making process varies depending on the electoral system. Majoritarian governments are likely to satisfy preferences of both well-organised globalisation losers who view social standards as a private good and loosely organised fair traders, while PR governments tend to cater to the fair traders who view social standards as a public good. These patterns of interest representation determine the strength of social standards in various PTAs signed by the countries with different electoral systems.

North American Free Trade Agreement (NAFTA) is the first N-S PTA to include social standards and is the prime example of such protection by a majoritarian government. Its side agreements on labour and the environment were specifically developed to ensure a smooth passage through the US Congress. The Trade Policy Act (2002) mandated the United States Trade Representative (USTR) to include enforceable labour and environmental standards in all American trade deals. The Bipartisan Trade Deal (2007) that replaced the Act contains the same condition but refers to internationally recognised core 
labour rights and multilateral environmental agreements. This case shows how labour and environment lobbies were able to effectively tie the hands of American trade negotiators (Destler, 2007). On the other hand, PTAs signed by the EU, with a supranational PR electoral body, or the European Free Trade Association (EFTA) do not contain enforceable social standards.

An alternative hypothesis is that the receptiveness of governments to lobbying pressures depends on the government's ideological orientation. Leftist governments signing PTAs may have incentives to promote and adopt stronger and more comprehensive social standards in their PTAs. However, we do not expect this to be the case. Consider, for example, the initial opposition to labour and environmental chapters in the early 2000s by President George W. Bush and the Republican-controlled Congress. To ensure the ratification of new trade deals and the renewal of Trade Promotion Authority in 2002, Congress and the executive, both ideologically opposed to linking trade and social protection, had to continue including social standards to satisfy the minority of influential Democrats and their constituents. On the other hand, in the EU, where leftist governments are traditionally stronger, but most of the member states (as well as the European Parliament) have PR systems, agreements have weaker social standards (International Labour Organization (ILO), 2016). These examples suggest that the design of electoral system is a more fundamental factor affecting the strength of social standards in PTAs through providing different channels for interest groups, regardless of the party in power. Nevertheless, party orientation could potentially enhance the effects of electoral rules. We return to this point in our empirical section.

In addition, trade policy-making rules, such as delegation of authority to the executive, might also play a role in determining trade agreements' outcomes. ${ }^{6}$ For example, Ehrlich (2007) shows how protectionist demands in the United States weakened over time as Congress progressively granted more authority on trade to the President representing one large constituency. However, the situation is different when it comes to social standards, which are explicitly stipulated in the Congressional mandate given to the President negotiating trade deals (Postnikov, 2019). Congressional politics is, therefore, decisive for social standards' design. At the same time, in the EU, the delegation of trade policymaking authority to the Commission is more extensive and the checks on its autonomy are weaker. As a result, the Commission is pushed to represent more diffuse interests of all EU citizens. We return to these points in the empirical section.

Only a few scholars argue that the links between domestic institutions and trade policy are more ambiguous and that plurality rule might be associated with more free trade (Rogowski and Kayser, 2002). McGillivray (2004) and Rickard (2012b) show how PR systems exhibit more protectionist bias than their plurality counterparts. Yet, these findings hinge on the degree of geographic concentration of special interests (Rickard, 2018). Busch and Reinhardt (2000), for example, show that geographic concentration serves as a bottom-up mobilisation mechanism attenuating collective action problems. Thus, it can make union activity more effective when workers from multiple industries demand the same protections that union leadership wants. Environmentalists (and, less commonly, some unions representing geographically dispersed industries) are a diffuse constituency. However, by working and lobbying with labour from concentrated industries, these environmentalists increase their effectiveness in majoritarian systems. When special interests are more diffuse, they will have greater success under PR rules (Rickard, 2012b, 2018). Generally, powerful unions represent key industries that are quite geographically concentrated; this is what determines their success in terms of influencing domestic policies 
(Busch and Reinhardt, 1999, 2000). Therefore, we acknowledge that interest group strength could be a moderating variable in the likelihood of majoritarian systems including comprehensive, enforceable social provisions and examine this in the empirical section.

Finally, we argue that the design of social standards in N-S PTAs is a product of Northern governments exporting their policy preferences in the course of bilateral negotiations. We rely on the two-level game theory to account for this (Putnam, 1988). It stipulates that the success of governments' negotiating strategies will depend on the size of the win-set, that is, the range of possible agreement outcomes acceptable to domestic audiences. Governments' hands in the Global North are effectively tied by domestic constituents who demand protection through social standards and whose support is needed for agreement ratification. Developing countries are thus forced to pursue a take-it-or-leaveit approach knowing that the successful passage of any agreement would require the acceptance and fulfilment of such stipulations (Kim, 2012). South-South PTAs rarely contain social standards as both governments and the public perceive them as Northern protectionism in disguise (Bastiaens and Postnikov, 2019). ${ }^{7}$

In sum, we assert that the electoral rules of the countries in the developed world that join N-S PTAs will be responsible for the design of social standards in these agreements. We hypothesise that PTAs signed by developed countries with plurality systems will contain stronger social standards, that is, wider in scope and more enforceable, than those pursued by their PR counterparts.

\section{Empirical analysis}

We now test our hypothesis that the electoral rules of Northern countries are a critical factor in the design of social standards in N-S PTAs. Our dependent variable is the strength of social standards in N-S PTAs. To begin our analysis, we collected a dataset of all such PTAs from Dür et al. (2014). ${ }^{8}$ It is the most comprehensive dataset in terms of the number of trade agreements included (see also Raess et al., 2018; Allee and Elsig, 2016). Online Appendices C.1 and C.2 list the treaties and countries under analysis. Next, we created an original variable on the strength (i.e. inclusion and enforceability) of social standards in each of these agreements. We researched and reviewed each trade agreement for (1) the inclusion of clauses or chapters on labour and environmental protections - a mention of labour or the environment in the preamble is not sufficient, it must be a separate article or chapter - and (2) legal enforcement mechanisms, that is, sanctions. ${ }^{9}$ Our final variable is coded on a scale from 0 to 3 with 0 signifying that the N-S PTA does not have labour or environmental provisions or sanctioning mechanisms; 1 indicating that the PTA has labour OR environmental provisions, but no sanctions; 2 representing PTAs with both labour AND environmental provisions, but no sanctions; and 3 representing PTAs with labour AND environmental provisions AND sanctions. ${ }^{10}$ The dependent variable is therefore a scale of the strength of social standards in N-S PTAs with greater values indicating more scope and enforceability. Online Appendices C. 3 and C.4 contain variable definitions, sources, and descriptive statistics. The level of analysis is each N-S country partnership. We code the EU as one developed country because it signs PTAs on behalf of the member states and its trade policy is supranational.

Our independent variable of interest is the type of electoral system in each PTA signatory in the global North. ${ }^{11}$ We collected this variable from the DPI (Beck et al., 2001). We employ a binary variable equal to 1 if the country under analysis has a purely majoritarian 
Table I. Political system of northern countries and the average social standard index score of their North-South preferential trade agreements.

\begin{tabular}{llll}
\hline & Plurality systems & $\begin{array}{l}\text { Proportional } \\
\text { representation systems }\end{array}$ & Mixed systems \\
\hline & Canada & Austria (1992-1994) & Australia \\
& Chile & European Union & Czech Republic \\
& New Zealand & Finland (1974-1994) & Hungary \\
& $(1980-1999)$ & Iceland & Japan \\
& United States & Norway & South Korea \\
& & Poland (1996-1998) & Mexico \\
& & Sweden (1975-1994) & New Zealand (2000-2010) \\
& & Turkey & Switzerland \\
Social standard & 1.73 & 0.67 & 0.12 \\
index average & & & \\
\hline
\end{tabular}

system. This variable equals 1 when 'legislators are elected using a winner-take-all / first past the post rule' (i.e. plurality systems) and equals 0 if not. ${ }^{12}$ Countries with a score of 0 for this variable thus have either a PR or mixed system. We treat the EU as a PR system because of the structure of the European Parliament that ratifies all EU PTAs after the Lisbon Treaty of 2009. ${ }^{13}$ The European Parliament is based on the principle of PR, similar to national parliaments in most of the member states. In the Online Appendix, we do estimate all our models excluding the EU because of the difficulty in measuring its electoral system and using alternative measures of electoral systems. We include the Southern country's electoral system in our empirical analyses. However, we expect only Northern majoritarian systems to be positive and statistically significant because developed countries act as policy-makers while their counterparts act as policy-takers.

Preliminary evidence suggests that Northern plurality countries are associated with more expansive and enforceable social standards in their PTAs. In fact, only Northern countries with majoritarian systems have signed N-S PTAs with sanctions. Table 1 lists the Northern countries in each electoral system classification and the average social standard index score for their N-S PTAs.

Figure 1 documents the variation in PTA design among Northern and Southern PTA signatories. The majority of N-S PTAs signed by Northern countries with PR systems do not contain social standards. In contrast, the majority of N-S PTAs signed by Northern countries with majoritarian systems do include social standards. A comparison of Southern signatories with PR and majoritarian systems does not exhibit a diverging pattern in their PTA design. Online Appendices C.5-C.10 provide additional graphical representations of social standards included in N-S PTAs signed by Northern and Southern countries with plurality, PR, and mixed electoral systems.

An important empirical concern is that countries with majoritarian systems might be more likely to sign PTAs than countries with PR systems. To address this selection concern, we estimated a t-test on the likelihood of Northern countries with PR and majoritarian systems to sign the PTAs in our dataset. To start, we collapse our dataset to sum the number of PTAs signed by each Northern country each year in our sample (1963-2015). We then operationalised the electoral system classification two ways. First, we assign 'mixed' and PR electoral systems a zero and majoritarian systems a one. In all, 139 observations include countries with mixed or PR systems with an average number of two PTAs 


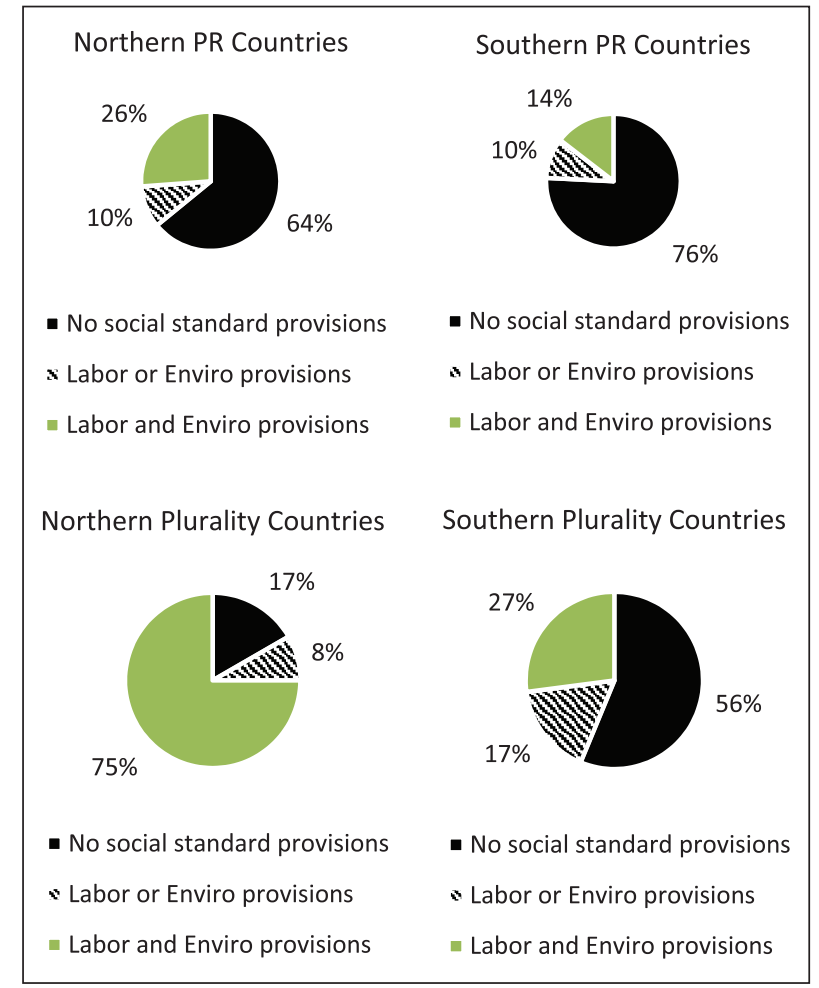

Figure I. North-South PTA design across various countries.

signed each year. Seventeen observations are countries with majoritarian systems who have signed an average of 1.6 PTAs a year. These means of PTAs signed were found to be statistically insignificant from each other ( $p$ value $>0.25$ ) indicating that both electoral systems are just as likely to form a PTA. This insignificant t-test result holds when limiting the sample to recent years, such as since 2000 ( $\mathrm{p}$ value $>0.52$ ). Then, operationalizing countries with PR systems as zero $(\mathrm{N}=84$, PTA mean 2.2) and mixed or majoritarian systems as one ( $\mathrm{N}=72$, PTA mean 1.6), the means of PTAs signed were found to be statistically significant from each other ( $\mathrm{p}$ value $>0.01$ ). However, limiting the sample to PTAs signed since 2000, the means of PTAs signed (1.7 and 1.5 for PR and mixed/majoritarian respectively) of the PR $(\mathrm{N}=40)$ and mixed or majoritarian systems $(\mathrm{N}=51)$ are statistically insignificant ( $\mathrm{p}$ value $>0.23$ ).

To test our hypothesis, we build on Rickard (2012a) and control for the level of trade (percent of GDP) and GDP growth (World Bank, 2016) of the Northern and Southern signatories in our estimations. We expect that more trade and GDP growth in Northern countries will be positively associated with the strength of social standards. More exposed (Northern) countries are more susceptible to the race to the bottom and are, therefore, predicted to have stronger measures, that is, social standards, to mitigate and prevent these 'negative externalities' of globalisation. We do not expect the economic variables to be statistically significant in the Southern countries as they are the policy-takers in trade agreement negotiations. However, it is also plausible that more trade exposure is associated with weaker social standards in Southern countries. Southern countries do compete 
Table 2. Ordered probit estimation of social standards index.

\begin{tabular}{|c|c|c|c|c|}
\hline DV = Social standard index & 1 & 2 & $\begin{array}{l}3 \\
\text { (excluding US) }\end{array}$ & $\begin{array}{l}4 \\
\text { (excluding EU) }\end{array}$ \\
\hline \multirow[t]{2}{*}{ Plurality dummy } & $4.445 * * *$ & $7.954 * * *$ & $5.985^{* *}$ & $5.010 * * *$ \\
\hline & $(1.2 \mid 8)$ & $(1.962)$ & $(2.830)$ & $(0.868)$ \\
\hline Partner state: & $0.665^{*}$ & 0.248 & 0.291 & 0.883 \\
\hline Plurality dummy & $(0.391)$ & $(0.365)$ & $(0.367)$ & $(0.66 \mathrm{I})$ \\
\hline \multirow[t]{2}{*}{ GDP difference } & & $-0.186 * * *$ & $-0.187^{* * *}$ & $\left.1.34\right|^{* * *}$ \\
\hline & & $(0.0502)$ & $(0.0466)$ & $(0.350)$ \\
\hline \multirow[t]{2}{*}{ Trade (\% GDP) } & & -0.00364 & 0.00863 & 0.0142 \\
\hline & & $(0.0201)$ & $(0.0190)$ & $(0.0189)$ \\
\hline \multirow[t]{2}{*}{ Partner state: Trade (\% GDP) } & & -0.00122 & -0.00248 & -0.00639 \\
\hline & & $(0.00298)$ & $(0.00420)$ & $(0.00759)$ \\
\hline \multirow[t]{2}{*}{ GDP growth } & & -0.0381 & -0.0595 & -0.105 \\
\hline & & $(0.167)$ & $(0.173)$ & $(0.206)$ \\
\hline \multirow[t]{2}{*}{ Partner state: GDP growth } & & 0.0239 & 0.0278 & -0.0147 \\
\hline & & $(0.0369)$ & $(0.0379)$ & $(0.0597)$ \\
\hline \multicolumn{5}{|l|}{ Left executive } \\
\hline \multicolumn{5}{|l|}{ Partner state: Left executive } \\
\hline \multicolumn{5}{|l|}{ Interest group strength } \\
\hline \multicolumn{5}{|l|}{$\begin{array}{l}\text { Partner state: Interest group } \\
\text { strength }\end{array}$} \\
\hline \multirow[t]{2}{*}{ Cut I constant } & $1.386 * * *$ & -2.683 & -2.048 & $39.64 * * *$ \\
\hline & $(0.423)$ & $(1.793)$ & $(\mathrm{I} .67 \mathrm{I})$ & $(10.33)$ \\
\hline \multirow[t]{2}{*}{ Cut 2 constant } & $1.772 * * *$ & -1.960 & -1.289 & $40.62 * * *$ \\
\hline & $(0.55 \mathrm{I})$ & $(1.684)$ & $(1.552)$ & $(10.45)$ \\
\hline \multirow[t]{2}{*}{ Cut 3 constant } & $4.18 I^{* * *}$ & 1.335 & 2.249 & $41.53 * * *$ \\
\hline & $(0.5 \mid 2)$ & (1.853) & $(1.650)$ & $(10.46)$ \\
\hline Observations & 406 & 332 & 316 & 231 \\
\hline
\end{tabular}

DV: dependent variable. Robust standard errors in parentheses. $*_{\mathrm{p}}<0 . \mathrm{I}$; ** $\mathrm{p}<0.05$; *** $\mathrm{p}<0.01$.

with each other for offering weaker standards, providing pools of cheap labour and acting as pollution havens. In all regressions we also include the difference in GDP (logged) between the Northern and Southern countries to control for power differentials across signatories.

We estimate an ordered probit model with robust standard errors clustered by treaty. Upon including our critical control variables, the sample includes treaties signed between 1976 and 2012. Since electoral institutions rarely change over time and are not designed for trade agreement purposes, much of the variation exploited by this analysis is crossnational. Reverse causality is therefore not a primary concern.

Table 2 presents the estimation results (see columns 1 and 2). The predicted probabilities for the inclusion of social standards by Northern majoritarian countries (the baseline of comparison is PR and mixed systems) is detailed in Figure 2. There is a 10\% predicted probability that a Northern majoritarian country will have environmental and labour protections and no sanctions, and close to a $90 \%$ predicted probability of environmental and labour protections and sanctions in their PTAs. The predicted probability is close to zero 


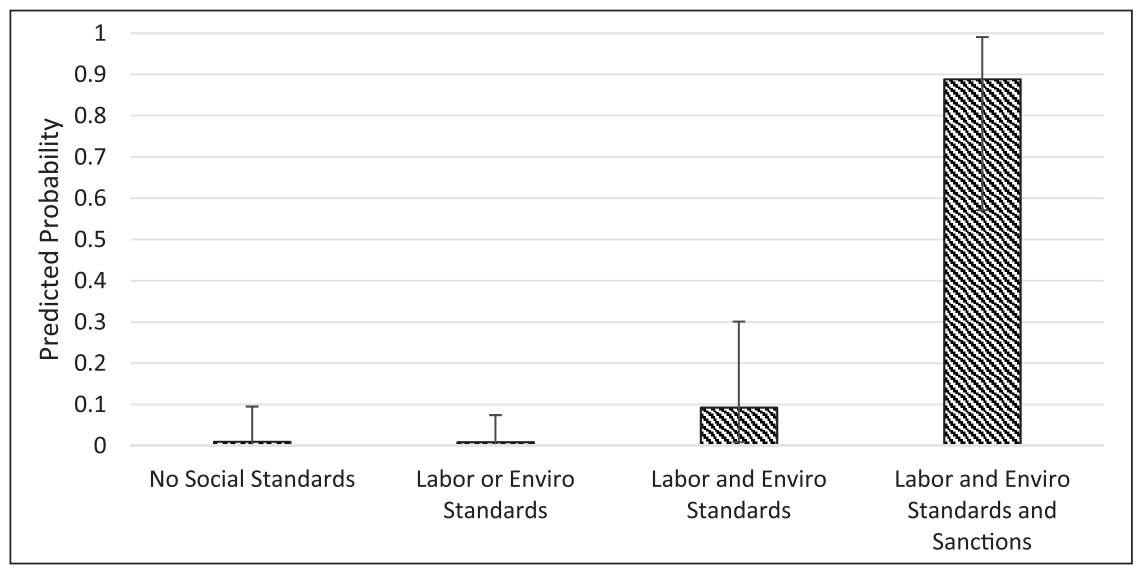

Figure 2. Predicted probabilities of social standard inclusion among plurality countries (plurality $=\mathrm{I}$, mixed and $\mathrm{PR}=0$ ) $($ Table 2 , column 2).

that a majoritarian system would have no social standards in their PTAs. Our findings indicate that plurality rule is associated with both more social protections and more enforceability of those protections. Some examples of N-S PTAs signed by majoritarian Northern states with labour and environmental standards and sanctions are CanadaPanama in 2010 and US-Bahrain in 2004. Recent N-S PTAs signed by mixed electoral system Northern states with no social standards include Australia-Malaysia in 2012 and Japan-Peru in 2011. Across these N-S PTAs, the Southern partner countries' electoral institutions include both plurality and PR systems, not exhibiting an empirical pattern.

To address concerns regarding the coding of the EU or that the leader of the liberal international order, the United States, is driving our results, we exclude the EU and United States from the sample. Table 2, column 3 excludes the US PTAs from the sample and Table 2, column 4 excludes EU PTAs. Importantly, we also conduct every following robustness check on a sample excluding the EU, see Online Appendix B for all the estimation results.

To assess alternative hypotheses, we control for partisanship and interest group strength. Following Rickard (2012a), we control for the partisan leaning of the executive (Dür et al., 2014). It is a scale from 1 to 3 with 1 equalling a right, 2 a centre, and 3 a left executive in power. For the party orientation of the EU we use the party affiliation of the Commission president prior to assuming the post. Leftist Northern governments might have stronger, more inclusive social standards if they are more responsive to constituent interests and lobbyists. Finally, we account for the strength of interest groups with V-Dem's index of civil society participation: 'Are major CSOs routinely consulted by policymakers; how large is the involvement of people in CSOs; are women prevented from participating; and is legislative candidate nomination within party organization highly decentralized or made through party primaries?' (Coppedge et al., 2017). We expect more interest group strength, or higher values of this civil society index, to be positively correlated with social standard strength. In all our regressions we include these controls for both the Northern and the Southern signatories. Table 3 contains these results.

It is also plausible that either or both partisanship and interest group strength have a conditional relationship with the electoral system in predicting the strength of social 
standards in PTAs. We thus interact both partisanship and interest group strength with the binary plurality variable in Table 3 . We expect the Partisanship $\times$ Plurality variable to be statistically insignificant as partisanship is not a key predictor of social standard strength. However, because our argument implies that interest groups have more political power in majoritarian systems, we predict that the Interest Group $\times$ Plurality Variable will be positive and statistically significant. Countries with majoritarian systems and strong interest groups should have the strongest social standards. Our expectations are confirmed.

As robustness checks, we include additional control variables and employ alternative specifications of the variables of interest, the sample, and the model. ${ }^{14}$ First, we control for common language across and the total distance between the treaty partners. Following Lechner (2016), we also control for bilateral trade between the Northern and Southern PTA signatories. ${ }^{15}$ We then include measures of divided government and tariff rates. ${ }^{16}$ Divided government is operationalised using the vote share of opposition parties and a checks and balance measure which accounts for opposition controls of the legislature (see Dür et al., 2014). The checks measure accounts for the number of parties in the government coalition needed to maintain a majority in parliamentary systems and, in presidential systems, if the president's party has a majority in the legislature. It is therefore a measure of the broader institutional environment and authority and power of the executive. We also include the ideology of the largest government and opposition parties in the legislature to address concerns that the party orientation of the legislature affects treaty design (Beck et al., 2001). ${ }^{17}$ To address the compensation hypothesis (Hays et al., 2005), we control for government spending (percent of GDP) from the World Bank (2016). Social standards and government spending are both mechanisms to increase public support for free trade - they could thus be complements or substitutes. Finally, we employ both GDP and GDP per capita to capture both economic size and economic development. More specifically, we control for GDP per capita, the difference in GDP per capita across Northern and Southern countries, and GDP and GDP per capita logged and squared for both Northern and Southern states. The logged and squared terms account for the environmental Kuznets curve. Online Appendix Tables A.1 and A.2 present the robust estimation results.

Online Appendix A.3 employs alternative specifications of electoral systems. We first use the DPI's plurality dummy variable which equals 1 when 'legislators are elected using a winner-take-all / first past the post rule' (i.e. plurality systems) and equals 0 if not. Mixed systems are coded as one in this specification. Then, we include both plurality and PR binary variables, with mixed systems as the base category. We also employ a scaled variable equal to 1 for pure PR systems, 2 for mixed systems, and 3 for pure plurality systems. All results are robust. The predicted probabilities for Northern plurality, mixed, and PR systems are detailed in Figure 3. For plurality systems, stronger social standards are more likely to occur; PR systems experience the opposite - more comprehensive or enforceable social provisions are less likely to exist in their N-S PTAs. Northern mixed and PR systems are much more likely to have no social standards in their N-S PTAs (PR systems' predicted probability is over $90 \%$, mixed systems' predicted probability is $33 \%$ ) than majoritarian systems (3\%). Plurality systems have a predicted probability of $87 \%$ of having both social standards and sanctions in their N-S PTAs; mixed systems have the highest probability of having labour and environmental standards but not sanctions (45\% compared to less than $1 \%$ for both pure plurality and PR systems). This suggests that the pressure from interest groups in mixed systems is often strong enough for governments to include social standards, but not enough to make them fully enforceable. 
Table 3. Ordered probit estimation of social standards index, controlling for potential conditional relationships.

\begin{tabular}{|c|c|c|c|c|}
\hline DV $=$ Social standard index & 1 & 2 & 3 & 4 \\
\hline Plurality dummy & $\begin{array}{l}7.275 * * * \\
(2.573)\end{array}$ & $\begin{array}{c}9.877 * * \\
(3.937)\end{array}$ & $\begin{array}{l}7.657 * * * \\
(2.030)\end{array}$ & $\begin{array}{l}-58.70 * * * \\
(14.59)\end{array}$ \\
\hline $\begin{array}{l}\text { Partner state: Plurality } \\
\text { dummy }\end{array}$ & $\begin{array}{c}0.241 \\
(0.396)\end{array}$ & $\begin{array}{l}-0.229 \\
(0.773)\end{array}$ & $\begin{array}{c}0.359 \\
(0.407)\end{array}$ & $\begin{array}{l}-1.107 \\
(1.111)\end{array}$ \\
\hline Left executive & $\begin{array}{l}-1.247 * * \\
(0.499)\end{array}$ & $\begin{array}{l}-1.026 * * \\
(0.477)\end{array}$ & & \\
\hline $\begin{array}{l}\text { Partner state: Left } \\
\text { executive }\end{array}$ & $\begin{array}{l}-0.00424 \\
(0.200)\end{array}$ & $\begin{array}{l}-0.101 \\
(0.284)\end{array}$ & & \\
\hline $\begin{array}{l}\text { Plurality Dummy } \times \text { Left } \\
\text { Executive }\end{array}$ & & $\begin{array}{l}-1.617 \\
(2.736)\end{array}$ & & \\
\hline $\begin{array}{l}\text { Partner state: Plurality } \\
\text { Dummy } \times \text { Left Executive }\end{array}$ & & $\begin{array}{c}0.25 I \\
(0.36 I)\end{array}$ & & \\
\hline Interest group strength & & & $\begin{array}{c}0.104 \\
(2.516)\end{array}$ & $\begin{array}{l}-2.840 \\
(2.380)\end{array}$ \\
\hline $\begin{array}{l}\text { Partner state: Interest } \\
\text { group strength }\end{array}$ & & & $\begin{array}{c}0.496 \\
(0.871)\end{array}$ & $\begin{array}{l}-0.784 \\
(1.299)\end{array}$ \\
\hline $\begin{array}{l}\text { Plurality Dummy } \times \text { Interest } \\
\text { Group Strength }\end{array}$ & & & & $\begin{array}{l}71.01 * * * * \\
(16.90)\end{array}$ \\
\hline $\begin{array}{l}\text { Partner state: Plurality } \\
\text { Dummy } \times \text { Interest Group } \\
\text { Strength }\end{array}$ & & & & $\begin{array}{c}2.308 \\
(1.657)\end{array}$ \\
\hline GDP difference & $\begin{array}{c}-0.185^{* * *} \\
(0.0502)\end{array}$ & $\begin{array}{c}-0.180 * * * \\
(0.0485)\end{array}$ & $\begin{array}{c}-0.187 * * * \\
(0.0448)\end{array}$ & $\begin{array}{c}-0.197^{* * *} \\
(0.0413)\end{array}$ \\
\hline Trade (\% GDP) & $\begin{array}{l}0.00997 \\
(0.0276)\end{array}$ & $\begin{array}{c}0.0220 \\
(0.0228)\end{array}$ & $\begin{array}{l}-0.00786 \\
(0.0214)\end{array}$ & $\begin{array}{l}0.0156 \\
(0.0192)\end{array}$ \\
\hline $\begin{array}{l}\text { Partner state: } \\
\text { Trade (\% GDP) }\end{array}$ & $\begin{array}{r}-0.0215^{* *} \\
(0.00966)\end{array}$ & $\begin{array}{r}-0.0212 * * \\
(0.00977)\end{array}$ & $\begin{array}{c}-0.000367 \\
(0.00272)\end{array}$ & $\begin{array}{r}-0.00118 \\
(0.00382)\end{array}$ \\
\hline GDP growth & $\begin{array}{l}0.187 \\
(0.225)\end{array}$ & $\begin{array}{l}0.168 \\
(0.221)\end{array}$ & $\begin{array}{c}-0.0539 \\
(0.161)\end{array}$ & $\begin{array}{c}-0.0849 \\
(0.151)\end{array}$ \\
\hline $\begin{array}{l}\text { Partner state: } \\
\text { GDP growth }\end{array}$ & $\begin{array}{c}0.0103 \\
(0.0449)\end{array}$ & $\begin{array}{l}0.00948 \\
(0.0440)\end{array}$ & $\begin{array}{c}0.0360 \\
(0.0362)\end{array}$ & $\begin{array}{c}0.0370 \\
(0.0366)\end{array}$ \\
\hline Cut I constant & $\begin{array}{l}-5.226 * * \\
(2.584)\end{array}$ & $\begin{array}{l}-4.227^{* *} \\
(2.052)\end{array}$ & $\begin{array}{l}-2.398 \\
(1.997)\end{array}$ & $\begin{array}{l}-4.677 * * \\
(2.225)\end{array}$ \\
\hline Cut 2 constant & $\begin{array}{l}-4.382 \\
(2.672)\end{array}$ & $\begin{array}{l}-3.377 \\
(2.156)\end{array}$ & $\begin{array}{c}-1.734 \\
(1.978)\end{array}$ & $\begin{array}{r}-3.958^{*} \\
(2.264)\end{array}$ \\
\hline Cut 3 constant & $\begin{array}{c}-1.082 \\
(3.259)\end{array}$ & $\begin{array}{c}-0.0255 \\
(2.714)\end{array}$ & $\begin{array}{c}1.525 \\
(2.194)\end{array}$ & $\begin{array}{c}-0.350 \\
(2.324)\end{array}$ \\
\hline Observations & 156 & 156 & 312 & 312 \\
\hline
\end{tabular}

DV: dependent variable. Robust standard errors in parentheses. $*_{\mathrm{p}}<0.1$; **p $<0.05 ; *^{*} \mathrm{p}<0.01$.

As an additional check in the independent variable specification, we lag the Dür et al. (2014) left executive variable by 3 years to control for government partisanship during the PTA negotiation period. See Online Appendix Table A.3.

We employ an alternative coding of the dependent variable whereby the scale does not include the threat of sanctions. The EU, for example, relies on civil society dialogue and 


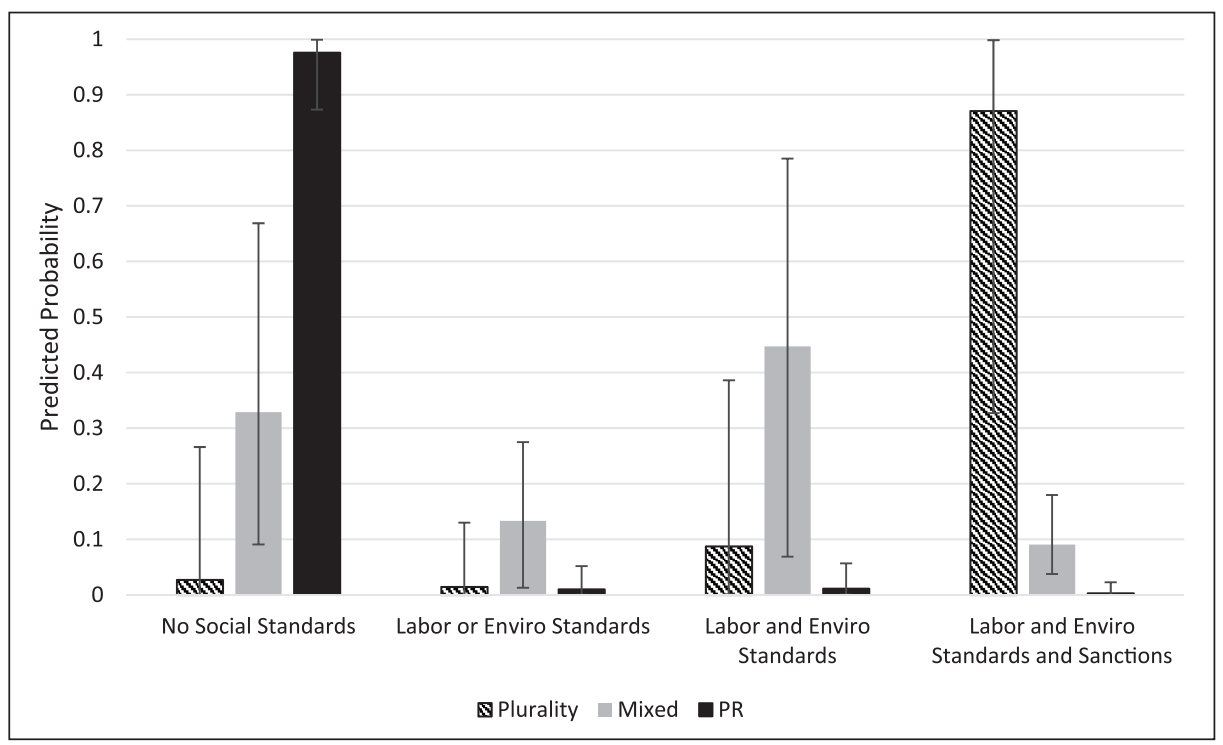

Figure 3. Predicted probabilities of social standard inclusion across all electoral systems (Online Appendix Table A.3, column 3).

soft power to implement its agreements, and this design has been shown to be effective in changing social indicators (ILO, 2016). Therefore, the emphasis on sanctions as the highest form of compliance could be challenged. Essentially, this dependent variable is scaled from 0 to 2, with 0 equalling no social provisions, 1 labour or environmental provisions, and 2 labour and environmental provisions. ${ }^{18}$ Plurality systems are still more likely to have broader, comprehensive social standards (Online Appendix Table A.4). The predicted probabilities are presented in Figure 4. Using this alternative coding of the dependent variable, there is a statistically significant (large) difference in the predicted probability of having no social standards in comparison to having both labour and environmental provisions in Northern majoritarian countries. For these countries, there is a high predicted probability of including both social standards in N-S PTAs (91\%). Mixed and PR systems are more likely to exclude social standards in their N-S PTAs (47\% and 94\% respectively compared to less than $1 \%$ for majoritarian systems). Interestingly, since mixed systems exhibit features of both PR and plurality counterparts, their propensity to sign PTAs with social standards is somewhat higher, yet the enforcement remains weak.

Finally, the results are also robust to alternative samples, such as excluding Canada or the United States, Canada, and the EU from the sample (Online Appendix Table A.5). We include this check to address concerns that these Northern countries, who sign many PTAs with social standards, are driving the results. We also estimate our model on only recently signed PTAs (Online Appendix Table A.5) to address concerns that the long time-period in our main models is adding noise to the estimations. We include PTAs signed since 1995 , but our results are robust to alternative time periods such as since 1990, 2000, or 2005. Next, we code 'Northern' countries as long-standing OECD (Organisation for Economic Co-Operation and Development) members. Hence, the following countries that 'switch' from South to North in our original sample would be coded here as Southern for all years under analysis: Chile, Czech Republic, Estonia, Hungary, Israel, Korea, Latvia, Lithuania, Mexico, Poland, Slovak Republic, and Slovenia. See 


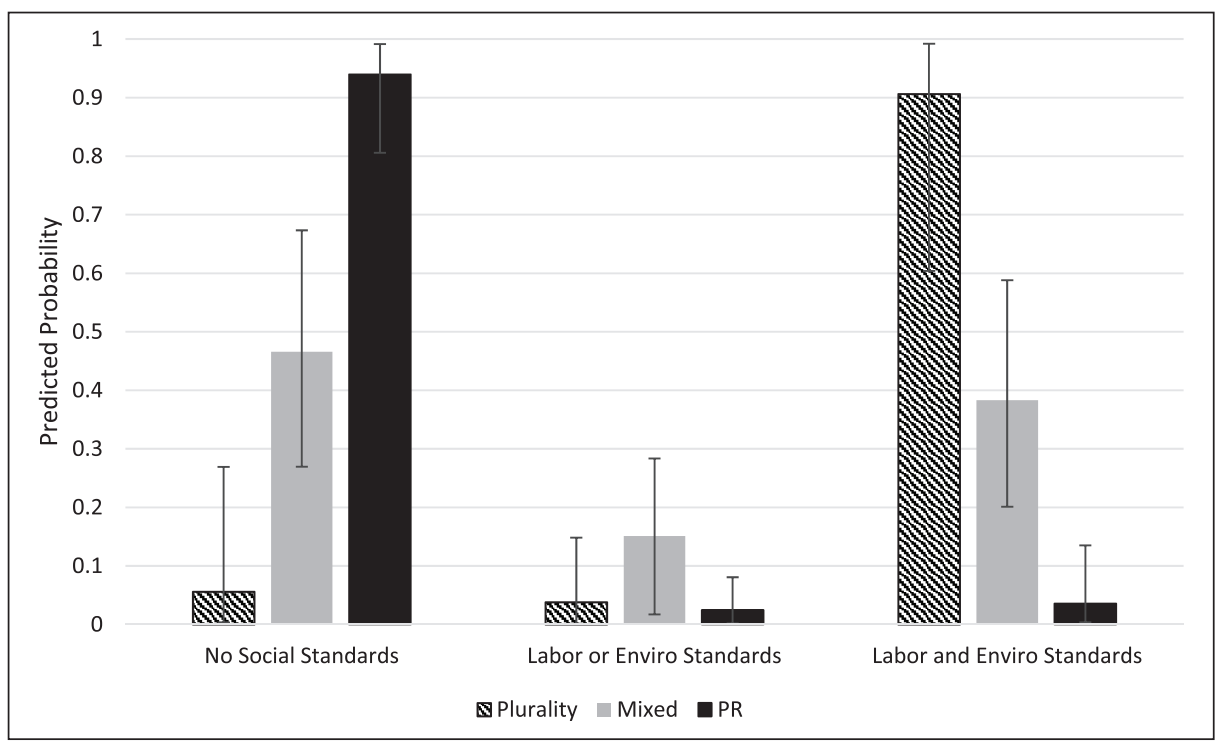

Figure 4. Predicted probabilities of social standard inclusion (alternative measure with no sanctions) across all electoral systems (Online Appendix Table A.4, column 5).

Online Appendix Table A.5. As a final alternative sample, we exclude the following nontraditional PTAs from our sample: Association of Caribbean States, Cotonou Agreement, D8 PTA, and Lome IV. See Online Appendix Table A.5. Results are robust to clustering the standard errors by country (Online Appendix Table A.6). Clustering by country addresses concerns of country dependencies in the data.

Overall, our estimations provide support to our hypothesis that the electoral system of Northern countries is a key predictor in the strength and inclusion of social standards in N-S PTAs. Northern states with plurality systems are more likely to have deeper and legally binding social clauses in their trade agreements.

\section{Conclusion}

In this article, we argue that governments in the Global North use a certain type of regulation to protect the potential losers of trade liberalisation - social standards in PTAs. Thus, the available toolkit of protectionist measures extends beyond traditional tariff measures or subsidies into the realm of social regulation. The latter is particularly salient in the current era characterised by, on the one hand, the shift towards trade bilateralism and, on the other, continued lowering of tariffs and NTBs. We highlight, however, that not all governments design social standards in PTAs in the same way. Electoral rules shape societal mobilisation patterns and respective government responses and, therefore, also the scope and enforcement of social standards in PTAs. Majoritarian governments captured by certain interest groups are prone to use fully enforceable labour and environmental standards to protect these constituents. Governments in PR systems are less likely to do so: instead, they rely on soft implementation measures and standards limited in scope, to address constituents' fair trade concerns. Hence, we find that majoritarian systems exhibit a social protectionist bias, in addition to previously asserted traditional one. Our findings highlight 
an interesting paradox - PR systems produce generally stronger social protections domestically than their plurality counterparts, but in international trade policy it is the reverse.

Our analysis points to how social standards are a genuine way to compensate groups on the losing end of trade liberalisation, albeit only in the Global North where societal mobilisation around new trade issues is increasing and where political actors begin to respond to societal pressures (Young, 2019). Considering that governments' budgets are under strain and welfare spending is relatively costly, it is little surprise that social standards are increasingly viewed as an important vehicle of protection and, perhaps, a new form of embedded liberalism in the developed world (Bastiaens and Postnikov, 2019). Labour and environmental provisions in N-S PTAs are increasingly perceived as a way to achieve fair trade by constituents in the developed world and are likely to buy public support for further trade liberalisation (Bastiaens and Postnikov, 2019; Ehrlich, 2018). Yet social standards are a different kind of protection because, given proper enforcement and implementation, they may contribute to a race to the top in the developing world when the conditions on the ground are propitious (Bastiaens and Postnikov, 2017). ${ }^{19}$ Thus, social protectionist bias might not be such bad news for the global economy grappling with social and political exigencies of globalisation, but only if Northern governments supplement social standards with financial assistance and dialogues with civil society. Using the full range of judicial mechanisms in PTAs for the proper enforcement and implementation of social standards is also critical. Without such efforts, social standards may remain simply a form of green and labour protectionism.

Compared to its traditional counterpart based on tariffs and subsidies, social protectionism is more nuanced, stemming from the preferences of both fair traders who view social protection as a global public good and globalisation losers who view it as a private one. This logic makes social protectionism a potent policy instrument with a potential to unite diverse anti-trade constituencies and boost the legitimacy of free trade policies. To understand its political logic, one needs to pay close attention to both domestic institutional factors and the rise of new trade politics manifesting in the design of regulatory provisions in trade deals (Young, 2016). Future studies should continue to explore varieties of this new protectionism and its effects. While the use of NTBs in the open economy has been acknowledged, the emergence of a new, regulatory trade agenda provides governments with further opportunities for 'optimal obfuscation' (Kono, 2009). Understanding the politics of this regulatory obfuscation by expanding the existing accounts of trade policy-making to include non-trade issues would be a valuable research agenda, and our piece should be viewed as a step in this direction.

\section{Funding}

The author(s) received no financial support for the research, authorship, and/or publication of this article.

\section{ORCID iD}

Evgeny Postnikov (iD https://orcid.org/0000-0002-4366-8401

\section{Supplemental material}

Additional supplementary information may be found with the online version of this article.

\section{Notes}

1. Governments also sign preferential trade agreements (PTAs) for security benefits/alliances, reducing trade diversion (Ravenhill, 2017), or political trade dependencies (Manger and Shadlen, 2014). 
2. For example, position papers by the American labour unions demand increasing enforceability: https:// laborrights.org/in-the-news/statement-afl-cio-president-john-sweeney-increase-violence-againstcolombian-trade

3. The U.S. Chamber of Commerce (2003) explicitly renounced enforceable social standards while praising the commercial benefits.

4. We thank an anonymous reviewer for this point.

5. We thank an anonymous reviewer for this point.

6. We thank an anonymous reviewer for highlighting this dynamic.

7. The recent inclusion in some trade agreements among developing countries (in a rather weak form) is likely to be driven by competitive pressures (Milewicz et al., 2016). Indeed, empirical estimations of emerging market PTAs indicate that electoral system is not a determining factor of social standard inclusion.

8. We exclude defunct agreements.

9. Most of trade agreements were available on the following websites: bilaterals.org; trade.ec.europe.eu; ustr. gov.

10. There are no trade agreements with labour OR environmental standards AND sanctions. We are agnostic as to which exact groups would be able to capture policy process; hence, we coded PTAs with labour OR environmental provisions as 2 .

11. We define all OECD member states as Northern countries. OECD members are most likely to be policymakers because membership to the OECD entails prestige and power in the international market and development arenas. Furthermore, the OECD sets international standards and policies on global market strategies, green growth, and health and safety. Members routinely work with labour and other civil society organisations to devise socially responsible, welfare-enhancing globalisation policies. See www.oecd. org/about/.

12. If the Database of Political Institutions' (DPI) proportional representation (PR) and plurality variables are both equal to 1 , our independent variable of interest discussed here is coded as 0 . Specifically, the PR variable equals 1 if 'candidates are elected based on the percent of votes received by their party and/or if our sources specifically call the system "proportional representation".

13. Before the Lisbon Treaty, the Council of the EU - where countries with PR systems are dominant - was solely responsible for PTA ratification.

14. Rickard (2012a) highlights the possible role of federalism on trade policy. We do not control for the DPI variable authority, which equals 1 if 'state/provinces have authority over taxing, spending, or legislating' and 0 otherwise because of the lack of variation in federalism in the Northern countries. Approximately $95 \%$ of the Northern states' authority equals 1 .

15. Lechner (2016) indicates the importance of controlling for wage differentials across treaty partners. Unfortunately, the wage data had insufficient observations to effectively estimate our models.

16. Lohmann and O'Halloran (1994) demonstrate that divided government in the US context is conducive to protectionist policies as the opposition party in Congress can constrain the President's delegated authority. Tariff rates control for the level of trade protection in the country.

17. Results are also robust to including both the executive ideology and vote share of the opposition in the legislature.

18. See Allee and Peinhardt (2010) for a similar coding scheme.

19. The enforcement and implementation of social standards remains low due to political and legal costs, as evidenced by the failed US attempts to apply sanctions on Guatemala for failing to comply with labour standards in DR-CAFTA (Dominican Republic-Central America Free Trade Agreement).

\section{References}

Allee T and Elsig M (2016) Why do some international institutions contain strong dispute settlement provisions? New evidence from preferential trade agreements. Review of International Organization 11: 89-120.

Allee T and Peinhardt C (2010) Delegating differences: Bilateral investment treaties and bargaining over dispute resolution provisions. International Studies Quarterly 54(1): 1-26.

Baccini L, Dür A and Haftel YZ (2014) Imitation and innovation in international governance: The diffusion of trade agreement design. In: Dür A and Elsig M (eds) Trade Cooperation: The Purpose, Design and Effects of Preferential Trade Agreements. Cambridge: Cambridge University Press, pp.167-194.

Bastiaens I and Postnikov E (2017) Greening up: The effects of environmental standards in EU and US trade agreements. Environmental Politics 26(5): 847-869. 
Bastiaens I and Postnikov E (2019) Social standards in trade agreements and free trade preferences: An empirical investigation. Review of International Organizations. Epub ahead of print 1 May. DOI: 10.1007/ s11558-019-09356-y.

Beck T, Clarke G, Groff A, et al. (2001) New tools in comparative political economy: The Database of Political Institutions. World Bank Economic Review 15(1): 165-176.

Betz T (2017) Trading interests: Domestic institutions, international negotiations, and the politics of trade. The Journal of Politics 79(4): 1237-1252.

Bhagwati JN and Panagariya A (eds) (1996) The Economics of Preferential Trade Agreements. Washington, DC: AEI Press.

Bueno de Mesquita B, Smith A, Silverson RM, et al. (2003) The Logic of Political Survival. Cambridge, MA: MIT Press.

Busch ML and Reinhardt E (1999) Industrial location and protection: The political and economic geography of U.S. non-trade barriers. American Journal of Political Science 43(4): 1028-1050.

Busch ML and Reinhardt E (2000) Geography, international trade, and political mobilization in U.S. industries. American Journal of Political Science 44(4): 703-719.

Coppedge M, Gerring J, Lindberg SI, et al. (2017) V-Dem [Country-Year/Country-Date] Dataset v7.1. Varieties of Democracy (V-Dem) Project. Gothenburg: V-Dem Institute.

Dean A (2015) The gilded wage: Profit-sharing institutions and the political economy of trade. International Studies Quarterly 59(2): 316-329.

Destler IM (2007) American trade politics in 2007: Building bipartisan compromise. Policy Brief PB07-5. Washington, DC: Peterson Institute for International Economics.

Dür A, Baccini L and Elsig M (2014) The design of international trade agreements: Introducing a new dataset. The Review of International Organizations 9(3): 353-375.

Ehrlich SD (2007) Access to protection: Domestic institutions and trade policy in democracies. International Organization 61(3): 571-605.

Ehrlich SD (2010) The fair trade challenge to embedded liberalism. International Studies Quarterly 54(4): 1013-1033.

Ehrlich SD (2018) The Politics of Fair Trade: Moving beyond Free Trade and Protection. New York: Oxford University Press.

Evans CL (2009) A protectionist bias in majoritarian politics: An empirical investigation. Economics \& Politics 21(2): 278-307.

Grossman GM and Helpman E (2005) A protectionist bias in majoritarian politics. Quarterly Journal of Economics 120(4): 1239-1282.

Hafner-Burton EM (2005) Trading human rights: How preferential trade agreements influence government repression. International Organization 59(3): 593-629.

Hankla CR (2006) Party strength and international trade: A cross-national analysis. Comparative Political Studies 39(9): 1133-1156.

Hays JC, Ehrlich SD and Peinhardt C (2005) Government spending and public support for trade in the OECD: An empirical test of the embedded liberalism compromise thesis. International Organization 59(2): 473-494.

International Labour Organization (ILO) (2016) Handbook on Assessment of Labour Provisions in Trade and Investment Agreements. ILO.

Kim M (2012) Ex ante due diligence: Formation of PTAs and protection of labor rights. International Studies Quarterly 56(4): 704-719.

Kim SY (2015) Deep integration and regional trade agreements. In: Martin L (ed.) The Oxford Handbook of the Political Economy of International Trade. Oxford: Oxford University Press, pp.360-379.

Kono DY (2006) Optimal obfuscation: Democracy and trade policy transparency. American Political Science Review 100(3): 369-384.

Kono DY (2009) Market structure, electoral institutions, and trade policy. International Studies Quarterly 53(4): 885-906.

Lake DA (2009) Open economy politics: A critical review. Review of International Organizations 4(3): 219-244.

Lechner L (2016) The domestic battle over the design of non-trade issues in preferential trade agreements. Review of International Political Economy 23(5): 840-871.

Lechner L (2018) Good for some, bad for others: US investors and non-trade issues in preferential trade agreements. Review of International Organizations 13(2): 163-187.

Lizzeri A and Persico N (2001) The provision of public goods under alternative electoral incentives. American Economic Review 91(1): 225-239. 
Lohmann S and O'Halloran S (1994) Divided government and U.S. trade policy: Theory and evidence. International Organization 48(4): 595-632.

McGillivray F (2004) Privileging Industry: The Comparative Politics of Trade and Industrial Policy. Princeton, NJ: Princeton University Press.

Manger M (2009) Investing in Protection: The Politics of Preferential Trade Agreements between North and South. Cambridge: Cambridge University Press.

Manger MS and Shadlen KC (2014) Political trade dependence and North-South trade agreements. International Studies Quarterly 58(1): 79-91.

Mansfield E and Busch M (1995) The political economy of nontariff barriers: A cross-national analysis. International Organization 49(4): 723-749.

Meckling J and Hughes L (2017) Globalizing solar: Global supply chains and trade preferences. International Studies Quarterly 61(2): 225-235.

Milewicz K, Holloway J, Peacock C, et al. (2016) Beyond trade: The expanding scope of the nontrade agenda in trade agreements. The Journal of Conflict Resolution 62(4): 743-773.

Milner HV and Kubota K (2005) Why the move to free trade? Democracy and trade policy in the developing countries. International Organization 59(1): 107-143.

Nielson DL (2003) Supplying trade reform: Political institutions and liberalization in middle-income presidential democracies. American Journal of Political Science 47(3): 470-491.

Postnikov E (2019) Unravelling the puzzle of social standards' design in EU and US trade agreements. New Political Economy 24(2): 181-196.

Postnikov E and Bastiaens I (2014) Does dialogue work? The effectiveness of labor standards in EU preferential trade agreements. Journal of European Public Policy 21(6): 923-940.

Putnam RD (1988) Diplomacy and domestic politics: The logic of two-level games. International Organization 42(3): 427-460.

Raess D, Dür A and Sari D (2018) Protecting labor rights in preferential trade agreements: The role of trade unions, left governments, and skilled labor. Review of International Organization 13: 143-162.

Ravenhill J (2017) Regional trade agreements. In: Ravenhill J (ed.) Global Political Economy. Oxford: Oxford University Press, pp.141-173.

Rickard SJ (2012a) A non-tariff protectionist bias in majoritarian politics: Government subsidies and electoral institutions. International Studies Quarterly 56(4): 777-785.

Rickard SJ (2012b) Electoral systems, voters' interests and geographic dispersion. British Journal of Political Science 42(4): 855-877.

Rickard SJ (2018) Spending to Win. Political Institutions, Economic Geography, and Government Subsidies. Cambridge: Cambridge University Press.

Rogowski R (1987) Trade and the variety of democratic institutions. International Organization 41(2): 203223.

Rogowski R and Kayser MA (2002) Majoritarian electoral systems and consumer power: Price-level evidence from the OECD countries. American Journal of Political Science 46(3): 526-539.

U.S. Chamber of Commerce (2003) Implementation of U.S. bilateral free trade agreements with Latin America and Chile. Available at: http://www.uschamber.com/issues/testimony/2003/implementation-us-bilateralfree-trade-agreements-latin-america-and-chile (accessed 20 May 2019).

Weingast BR, Shepsle KA and Johnsen C (1981) The political economy of benefits and costs: A neoclassical approach to distributive politics. Journal of Political Economy 89(4): 642-664.

World Bank (2016) World development indicators. Available at: http://data.worldbank.org/data-catalog/worlddevelopment-indicators (accessed 18 August 2018).

Yandle B (1999) Baptists and bootleggers in retrospect. Regulation 22(3): 5-7.

Young A (2016) Not your parents' trade politics: The transatlantic trade and investment partnership negotiations. Review of International Political Economy 23: 345-378.

Young A (2019) Two wrongs make a right? The politicization of trade policy and European trade strategy. Journal of European Public Policy 26(12): 1883-1899. 